Language, Poetry and Poetics 



\section{Language, Poetry and Poetics}

The Generation of the 1890s:

Jakobson, Trubetzkoy, Majakovskij

Proceedings of the

First Roman Jakobson Colloquium, at the Massachusetts Institute of Technology October 5-6, 1984

edited by

Krystyna Pomorska $\dagger$

Elżbieta Chodakowska

Hugh McLean

Brent Vine

Mouton de Gruyter

Berlin · New York · Amsterdam 1987 
Mouton de Gruyter (formerly Mouton, The Hague)

is a Division of Walter de Gruyter \& Co., Berlin.

Library of Congress Cataloging-in-Publication Data

Roman Jakobson Colloquium (1st : 1984 : Massachusetts Institute of Technology)

Language, poetry and poetics.

Bibliography: $\mathrm{p}$.

Includes Index.

1. Jakobson, Roman, 1896-1982 -Congresses. 2. Linguistics-History-20th century-Congresses. 3. PoeticsCongresses. I. Pomorska, Krystyna. II. Title.

P85.J3R66 $1984 \quad 410^{\prime} .92^{\prime} 4$

$87-5679$

ISBN 0-89925-098-X (alk. paper)

Language, poetry and poetics : the generation of the 1890s: Jakobson, Trubetzkoy, Majakovskij ; proceedings of the 1. Roman Jakobson Colloquium, at the Massachusetts Inst. of Technology, October 5 - 6, 1984 / ed. by Krystyna Pomorska ... - Berlin ; New York ; Amsterdam : Mouton de Gruyter, 1987.

ISBN 3-11-010689-2 (Berlin)

NE: Pomorska, Krystyna [Hrsg.]; Roman Jakobson Colloquium $\langle 01,1984$, Cambridge, Mass. $\rangle$; Massachusetts Institute of Technology 〈Cambridge, Mass.〉

Printed on acid free paper.

(C) Copyright 1987 by Walter de Gruyter \& Co., Berlin. All rights reserved, including those of translation into foreign languages. No part of this book may be reproduced in any form - by photoprint, microfilm or any other means - nor transmitted nor translated into a machine language without written permission from Mouton de Gruyter, a Division of Walter de Gruyter \& Co., Berlin.

Typesetting and Printing: Arthur Collignon GmbH, Berlin. - Binding: Dieter Mikolai, Berlin. - Printed in Germany. 
Dedicated

to the memory of

Krystyna Pomorska Jakobson

(April 5, 1928 - December 19, 1986)

principal organizer of the Colloquium, esteemed Slavist and dear friend 
